\title{
Educational Social Skills and Repertoire of Children Differentiated by Behavior and Sex
}

\author{
Rafaela Pires Assis-Fernandes ${ }^{1}$ \\ Alessandra Turini Bolsoni-Silva ${ }^{1}$
}

\begin{abstract}
Our study sought to compare mothers' behavioral repertoire (educational social skills and negative practices) and maternal anxiety and depression indicators with children's behaviors (behavior problems and social skills), by assessing the variables "sex" (boys and girls) and "occurrence of behavior problems". The sample consisted of 20 children with behavior problems (clinical group), 20 without behavior problems (non-clinical group), their mothers and teachers. Reporting instruments were used with teachers and mothers and comparative analyzes were conducted between groups. The results indicated that the clinical group had higher rates of behavior problems and maternal depressive symptoms, whereas the non-clinical group showed more child social and educational social skills. Sex did not differ between groups. We concluded that maternal educational practices are more influenced by children's behaviors than by their sex.
\end{abstract}

Keywords: social skills, behavioral disorders, anxiety, depression, sex

\section{Habilidades Sociais Educativas e Repertório de Crianças Diferenciadas Por Comportamento e Sexo}

\begin{abstract}
Resumo: Este estudo objetivou comparar repertório comportamental de mães (habilidades sociais educativas e práticas negativas), indicadores de ansiedade e depressão maternos e comportamentos de crianças (problemas de comportamento e habilidades sociais), controlando as variáveis sexo (meninos e meninas) e ocorrência de problemas de comportamento. A amostra foi composta por 20 crianças com problemas de comportamento (grupo clínico), 20 sem problemas de comportamento (grupo não clínico), suas mães e professores. Foram utilizados instrumentos de relato com professores e mães e conduzidas análises comparativas entre os grupos. Os resultados indicaram que o grupo clínico apresentou maiores taxas em problemas de comportamento e sintomas de depressão materna, enquanto o grupo não clínico apresentou mais habilidades sociais infantis e habilidades sociais educativas. O sexo não diferenciou os grupos. Conclui-se que as práticas educativas maternas são mais influenciadas pelos comportamentos das crianças do que pelo sexo delas.
\end{abstract}

Palavras-chave: habilidades sociais, distúrbios do comportamento, ansiedade, depressão, sexo

\section{Habilidades Sociales Educativas y Repertorio de Niños Diferenciados por Comportamiento y Sexo}

\begin{abstract}
Resumen: Este estudio tuvo como objetivo comparar el repertorio conductual de madres (habilidades sociales educativas y prácticas negativas), los indicadores de ansiedad y depresión maternos y los comportamientos de los niños (problemas del comportamiento y habilidades sociales) diferenciados por las variables sexo (niños y niñas) y la aparición de problemas del comportamiento. La muestra consistió en 20 niños con problemas del comportamiento (grupo clínico), 20 niños sin problemas del comportamiento (grupo no clínico), sus madres y maestros. Se utilizaron instrumentos de informe con maestros y madres y se realizaron análisis comparativos entre grupos. Los resultados indicaron que el grupo clínico tenía tasas más altas de problemas del comportamiento y síntomas de depresión materna, mientras que el grupo no clínico tenía más habilidades sociales infantiles y habilidades sociales educativas. El sexo no se diferenció en los grupos. Se concluye que las prácticas educativas maternas están más influenciadas por los comportamientos de los niños que por el sexo de los mismos.
\end{abstract}

Palabras clave: habilidades sociales, trastornos de la conducta, ansiedad, depresión, sexo

${ }^{1}$ Universidade Estadual Paulista, Bauru-SP, Brazil.

Article derived from the master's thesis of the first author under the supervision of the second, defended in 2017, in the Graduate Program in Psychology of Development and Learning at the Faculty of Sciences, Universidade Estadual Paulista, campus Bauru.

Correspondence address: Rafaela Pires Assis-Fernandes. Universidade Estadual Paulista. Av. Eng. Luiz Edmundo Carrijo Coube, 14-01, Vargem Limpa, BauruSP, Brazil. CEP 17.033-360. E-mail: rafapires_13@hotmail.com
The interaction between parents and children is very important, since it favors skillful behaviors or indicate behavioral problems (Bolsoni-Silva, Loureiro, \& Marturano, 2016). As the child's first socialization agents, parents use several strategies to influence their children's behaviors, named by Gomide (2014) as "educational practices", which can both enable child development, the "positive practices", and be harmful to child 
development, identified as "negative practices". Bolsoni-Silva, Loureiro et al. (2016) proposed the study of social educational skills (habilidades sociais educativas parentais - hse-p), which can be divided into three behavioral classes: expression of feelings and coping, communication and establishment of limits.

In this line of research, studies have shown that more skilled parents are more able to provide their children with behavioral models to encourage new socially-skilled behaviors when setting limits and being responsive to their children's needs. On the other hand, parents with less hse-p may provide inappropriate models, have low consistency, reinforce problematic behaviors and are more aggressive when controlling their children's behaviors (Fantinato \& Cia, 2015; Van Vugt, Deković, Prinzie, Stams, \& Asscher, 2013). In addition to the scientific relevance, the study of parent-child interactions has social relevance, since the greater the description of related variables, the greater the chance of acting preventively, promoting social competence and reducing risks for child development.

Considering the mother as an important educational agent, assessing maternal mental health (depression and anxiety) becomes even more relevant. Children that live with mothers with a history of depression tend to have higher levels of school and behavior problems, lower self-esteem and less social competence (Mian, Tango, Lopes, \& Loureiro, 2009). Based on a literature review, Alvarenga, Oliveira and Lins (2012) concluded that maternal depression is a risk factor for child development, negatively affecting school-aged children. Moreover, maternal depression is evidently associated with the use of negative educational practices (Rakow et al., 2009). Maternal anxiety is also described as a risk factor for child development, since it can interfere with the responsiveness and quality of mother's care towards the baby (Airosa \& Silva, 2013). On the other hand, positive results of maternal anxiety were found in children's cognitive development associated with the fact that the anxious mother is more alert and active in interactions with her babies (Fraga, Linhares, Carvalho, \& Martinez, 2008). Most of the studies addressed the symptoms of anxiety in mothers in the pre and/or post-natal periods (Morais et al., 2017; Rodrigues \& Nogueira, 2016) and separation anxiety of mothers of children in early school age, with effects on the quality of socialization (Veríssimo, Alves, Monteiro, \& Oliveira, 2003). To the best of our knowledge, no studies that evaluated the maternal anxiety of school-aged children were found, justifying studies in this direction.

Regarding children's behaviors associated with sex, some studies (Mariano \& Bolsoni-Silva, 2016; Pizato, Marturano, \& Fontaine, 2014) affirmed that girls had higher scores for social skills and lower for externalizing behavior problems, despite having a higher prevalence of internalizing problems when compared with boys. However, other studies did not find the influence of sex on children's behavior (Martín, Granero, \& Ezpeleta, 2014; Massola \& Silvares, 2005), which indicates the need for further investigations to verify the influence of sex on behavior and social skills problems in schoolchildren.

Another line of research approaches the influence of sex on how parents use parenting practices. According to Trad
(1999), parents would maintain different rules in education, such as boys being raised so as not to show their feelings, while girls have more permission to express emotions. Sampaio and Vieira (2010) stated that parents seem to prefer children of the same sex. Wright et al. (2013) found a difference in parental tolerance, with fathers being more tolerant of boys' behavior problems, whereas mothers were equally tolerant of boys and girls' behaviors. Based on these findings, it is difficult to say if parenting practices towards boys and girls are influenced by children behavior or sex.

We identify some deficiencies in the aforementioned studies due to the different results when verifying the influence of the variable "sex", especially regarding children's behavior. Moreover, most of the studies referred to care services were conducted in children and not in the general population. Additionally, deficiencies regarding the methodology are also identified, considering that most of the available studies that compared the variable "sex" did not equally assess the presence and absence of behavior problems (Massola \& Silvares, 2005); also, they did not include the same number of boys and girls (Bueno, Grossi, Santos, Silva, \& Moura, 2011). Furthermore, most of these studies used only one source of information, either the teacher (Mariano \& Bolsoni-Silva, 2016; Pizato et al., 2014), or the parents (Bueno et al., 2011). Thus, our study approaches these deficiencies, raising the hypothesis that parenting practices could differ more due to child's behavior than to the child's sex.

Therefore, we observed that several variables influencing children's behaviors need to be addressed. Thus, our study adopted a case-control design to assess the variables "sex" and "occurrence of behavioral problems", having as outcome variables the hse-p, negative practices, maternal mental health (anxiety and depression), complaints of behavioral problems and children's social skills.

\section{Method}

\section{Participants}

Forty children participated in our study, 20 with diagnostic indicators of behavior problems (clinical group, composed of 10 girls and 10 boys), 20 without indicators of behavior problems (non-clinical group, composed of 10 girls and 10 boys), their mothers and 36 teachers ( 32 females and four males). The sample was of convenience, whose criteria were: being biological mothers; child with a clinical or borderline behavior through the evaluation of teachers and mothers in at least one of the scales, namely internalizing, externalizing and/or total (Teacher's Report Form - TRF, and Child Behavior Checklist - CBCL Achenbach \& Rescorla, 2001) to compose the clinical group, and child without any of these behaviors to the non-clinical group.

Children's age ranged between six and 11 years old, with a general average of 8.3 years old $(S D=1.6)$. The clinical and non-clinical groups had the same average age, 8.3 years old $(S D=1.6)$, with $p=1.000$ (Chi-square test). The average for the group of girls was 9.1 years old $(S D=1.4)$, whereas the 
average for the group of boys was 7.6 years old $(S D=1.4)$, with $p=0.057$. Regarding schooling, children attended between the 1st and 5th grades of elementary school. In the clinical group, the distribution was: children attending the 1st year (4), 2 nd year (2), 3rd year (6), 4th year (3) and 5th year (5); the nonclinical group had the following configuration: 1st year (5), 2 nd year (2), 3rd year (6), 4 th year (2) and 5 th year (5). Mothers were aged between 26 and 48 years, with a general average of 34.7 years $(S D=5.7)$, with no statistical differences in the comparison of groups: clinical and non-clinical $(\chi 2=0.000$; $p=1.000)$; boys and girls $(\chi 2=0.404 ; p=0.525)$. Regarding maternal education, 19 mothers $(47.5 \%)$ had up to eight years of study, and 21 mothers (52.5\%) studied over eight years, with no statistical differences between the groups: clinical and nonclinical $(\chi 2=0.902 ; p=0.342)$; boys and girls $(\chi 2=0.100$; $p=0.752)$. Regarding mother's work activities, the groups of mothers were also equivalent; 30 mothers worked $(75 \%)$ and 10 did not work $(25 \%)$, with an equal distribution between the groups: clinical and non-clinical $(\chi 2=0.000 ; p=1.000)$; boys and girls $(\chi 2=0.533 ; p=0.465)$. Among mothers, 26 mothers reported an income between 1 and 2 minimum wages (65\%), whereas 14 mothers reported between 3 or more minimum wages $(35 \%)$, with an equal distribution between groups: clinical and non-clinical $(\chi 2=1.321 ; p=0.540)$; boys and girls $(\chi 2=1.846 ; p=0.397)$.

\section{Instruments}

Teacher's Report Form (TRF) and Child Behavior Checklist (CBCL) (Achenbach \& Rescorla, 2001) were used to select the sample. The first directed to teachers' evaluation of the students' behaviors, and the second directed to the mothers' evaluation of the children's behaviors. The scores identify general patterns of behavior: externalizing, internalizing and total, and considered them as clinical, borderline or non-clinical. According to Bordin et al. (2013), the TRF is considered the gold standard for the assessment of behavior problems, since it has excellent psychometric properties, being widely used in several countries. However, it is still in the process of validation in Brazil. Regarding the CBCL, a preliminary validation study was conducted in Brazil, in which the answers of the mothers were compared with results of psychiatric evaluation, with a high correlation index (Bordin, Mari, \& Caeiro, 1995).

Interview Script for Parental Social Educational Skills (Roteiro de Entrevista de Habilidades Sociais Educativas Parentais - RE-HSE-P (Bolsoni-Silva, Loureiro et al., 2016) is a semi-structured interview to describe parental interactions. The answers obtained are coded in subcategories: hse-p, negative practices, children's social skills, context variables and complaints of behavior problems. Total Positive is obtained by adding the hse-p scores, children's social skills and context. In contrast, the Negative Total is obtained by adding the scores of negative practices and behavior problems. The instrument has good indicators of discriminant validity, construct and test-retest reliability, and has an internal consistency with 0.846 Cronbach's alpha (Bolsoni-Silva, Loureiro et al., 2016).
Socially Skilled Questionnaire (Questionário de Respostas Socialmente Habilidosas - QRSH-Pais). This instrument was used to measure the frequency of 18 socially-skilled behaviors of children, according to the mothers' report. After its completion, the scores are added up and the total score of social skills of the assessed child is obtained. The instrument presents good results considering the discriminative validity and has satisfactory internal consistency, with 0.82 Cronbach's alpha (Bolsoni-Silva, Marturano, \& Loureiro, 2011).

Patient Health Questionnaire (PHQ-4) (Kroenke, Spitzer, Williams, \& Löwe, 2009) was used to measure the occurrence of mothers' anxiety and depression symptoms. It consists of four items that assess the frequency of symptoms in the two weeks before the application. The Portuguese version was made by Pfizer (Copyright (C) 2005 Pfizer Inc., New York, NY). This instrument has good psychometric properties in a validation study with the general population (Löweet al., 2010). In Brazil, only the reliability of the two items related to depression (PHQ-2) was tested with a clinical sample, with a 0.64 Cronbach's alpha (Osório, Carvalho, Fracalossi, Crippa, \& Loureiro, 2012).

\section{Procedure}

Data collection. An authorization was obtained from the Department of Education of a city in the Midwest of the state of São Paulo to conduct the study. Subsequently, three Municipal Elementary Schools were contacted for the explanation of the objectives of the study to the school administration and teachers. Teachers were asked to indicate a child who they considered to have behavior problems and a child who did not have behavior problems, ensuring sample match regarding the number of boys and girls in each group. The girls in the clinical group and the non-clinical group had their ages matched, which also happened with the boys; however, there were variations in ages between the indications for girls and boys, since the girls had a higher average age, although the Chi-Square comparisons did not differentiate the groups $\left(\chi^{2}=3.636 ; p=0.057\right)$.

Afterwards, the mothers were contacted to authorize teachers to answer the TRF. When the indication of the teacher and the subsequent evaluation and correction of the TRF confirmed the adequacy to the criterion, the mothers were invited to participate in the study. A session was scheduled with each mother to apply the instruments (CBCL, RE-HSE-P, QRSH-Pais and PHQ-4) in a place chosen by the participants (school or residence). In cases, in which the CBCL correction indicated that the mother's assessment met the criteria for the child to participate in the study, the child was included. When the child did not meet the inclusion criteria, the participant was excluded, and teachers had to indicate another child and answer the TRF for each new indication. The instruments were applied at once in person. The application of the TRF with the teacher lasted approximately 30 minutes for each indication. The application with each mother lasted approximately two hours in the following order: CBCL, RE-HSE-P, QRSH-Pais and PHQ-4. Figure 1 schematically describes the sampling process. 


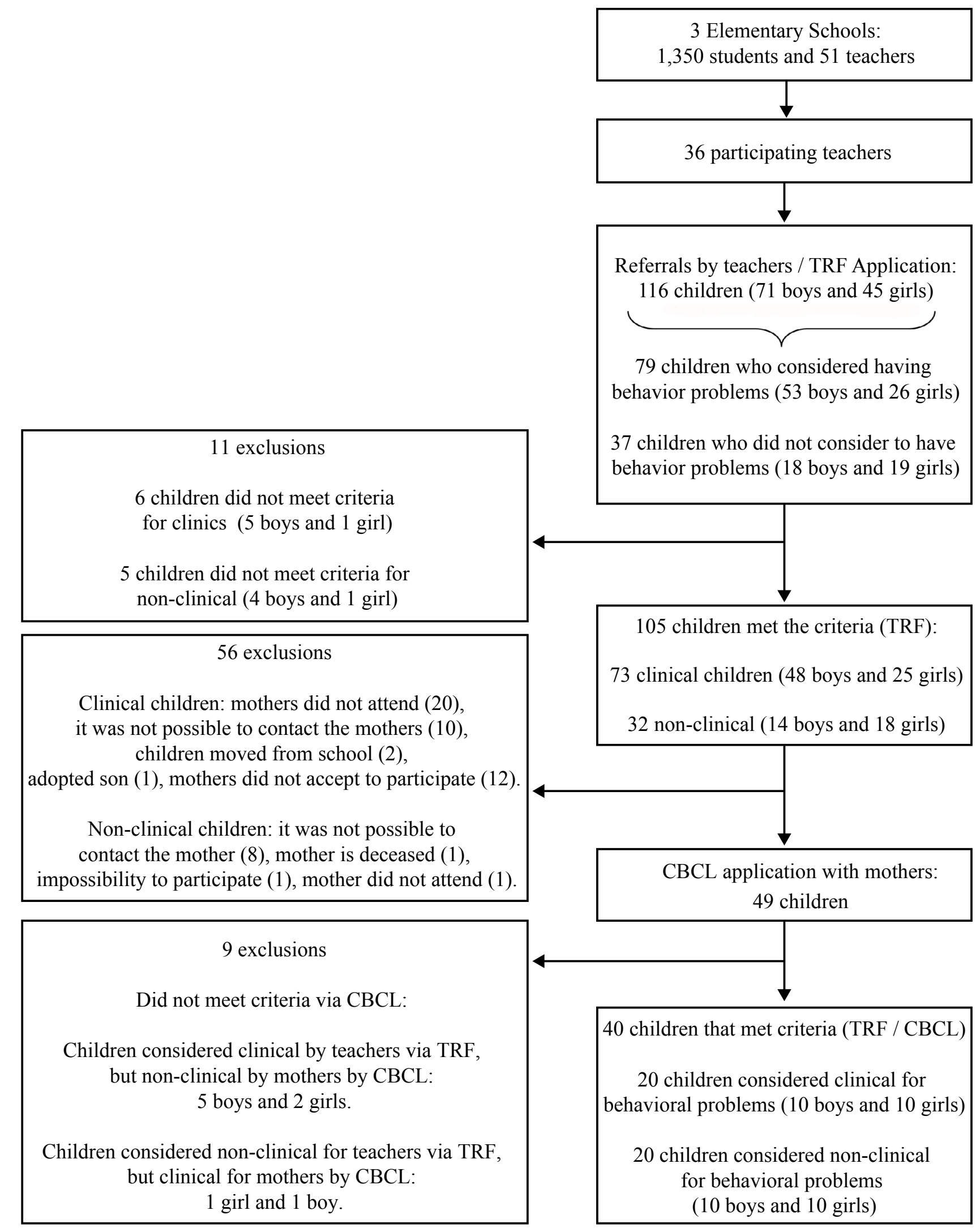

Figure 1. Sampling procedure. 
Data analysis. Teachers' (TRF) and mothers' (CBCL, RE-HSE-P, QRSH-Pais) answers were categorized according to the instructions of the instruments. Regarding PHQ-4, the sum of the four items (total score) was performed separately, as well as the sum of the depression and anxiety scores. The TRF and CBCL instruments were analyzed using the Software Assessment Data Manager (ADM 7.0) and provided the children's profiles for behavior problems, guaranteeing the result for the composition of the groups. The total sample of clinical and non-clinical groups was analyzed and compared in general and divided into subgroups to discriminate the specificities of the participants regarding the variable "sex". The numerical variables were compared regarding the presence or absence of behavioral problems and sex (Mann-Whitney $U$ test). In our analysis, a $p$ less than or equal to 0.05 was considered, in a $95 \%$ confidence interval.

\section{Ethical Considerations}

Our study was approved by the Research Ethics Committee (CEP), through process CAAE $n^{\circ}$ 50165515.1.0000.5398.

\section{Results}

The results are organized in three tables according to group comparisons: Clinical Group $\times$ Non-Clinical / Boys $\times$ Girls (Table 1), Clinical Girls $\times$ Non-Clinical Girls / Clinical Boys $\times$ Non-Clinical Boys (Table 2), Non-Clinical Girls $\times$ Non-Clinical Boys / Clinical Girls $\times$ Clinical Boys (Table 3).

Table 1

Comparisons between the Clinical $(n=20)$ and Non-Clinical $(n=20) /$ Boys $(n=20)$ and Girls $(n=20)$ Groups for the numerical variables of the RE-HSE-P, QRSH and PHQ-4 instruments (Mann-Whitney U test)

\begin{tabular}{|c|c|c|c|c|}
\hline \multirow{2}{*}{ Categories } & \multicolumn{2}{|r|}{ Non-clinical } & \multirow[b]{2}{*}{$U$} & \multirow[b]{2}{*}{$P$} \\
\hline & Mean $(\mathrm{S}$ & deviation) & & \\
\hline \multicolumn{5}{|l|}{ Diversity (RE-HSE-P) } \\
\hline HSE-P & $6.05(2.79)$ & $10.00(2.65)$ & 56.500 & 0.000 \\
\hline SS & $7.35(3.78)$ & $12.95(2.85)$ & 45.000 & 0.000 \\
\hline Context & $8.20(3.54)$ & $16.25(4.72)$ & 31.500 & 0.000 \\
\hline Negative Practices & $5.80(4.39)$ & $3.70(1.41)$ & 131.00 & 0.058 \\
\hline Behavior problem complaints (BP) & $7.55(3.89)$ & $2.40(1.39)$ & 44.500 & 0.000 \\
\hline Positive total & $20.35(8.62)$ & $42.65(9.29)$ & 17.000 & 0.000 \\
\hline Negative total & $14.70(9.15)$ & $8.1(2.26)$ & 132.000 & 0.065 \\
\hline Children's HS (QRSH) & $22.55(6.73)$ & $28.20(5.62)$ & 102.000 & 0.008 \\
\hline Total score (PHQ-4) & $5.70(3.85)$ & $2.90(2.65)$ & 108.500 & 0.012 \\
\hline Depression score (PHQ-4) & $3.30(1.97)$ & $1.20(1.10)$ & 72.500 & 0.000 \\
\hline Anxiety score (PHQ-4) & $2.40(2.40)$ & $1.70(1.68)$ & 154.500 & 0.207 \\
\hline \multirow{2}{*}{ Categories } & Boys & Girls & & \\
\hline & \multicolumn{2}{|c|}{ Mean (Standard Deviation) } & $U$ & $P$ \\
\hline \multicolumn{5}{|l|}{ Diversity (RE-HSE-P) } \\
\hline 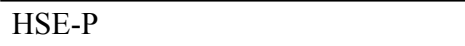 & $7.90(2.93)$ & $8.15(3.80)$ & 179.500 & 0.576 \\
\hline SS & $10.35(4.77)$ & $9.95(4.01)$ & 190.500 & 0.797 \\
\hline Context & $12.55(6.42)$ & $11.90(5.24)$ & 186.500 & 0.714 \\
\hline Negative Practices & $4.00(2.53)$ & $5.50(4.00)$ & 147.000 & 0.145 \\
\hline Behavior problem complaints (BP) & $5.05(3.88)$ & $4.90(3.99)$ & 186.000 & 0.703 \\
\hline Positive total & $33.00(14.61)$ & $30.00(14.29)$ & 177.500 & 0.543 \\
\hline Negative total & $11.55(6.98)$ & $11.25(7.94)$ & 183.500 & 0.654 \\
\hline Children's HS (QRSH) & $25.90(6.75)$ & $24.85(6.89)$ & 180.000 & 0.588 \\
\hline Total score (PHQ-4) & $3.55(2.54)$ & $5.05(4.28)$ & 170.000 & 0.412 \\
\hline Depression score (PHQ-4) & $2.10(1.71)$ & $2.40(2.40)$ & 193.500 & 0.857 \\
\hline Anxiety score (PHQ-4) & $1.45(1.05)$ & $2.65(2.65)$ & 150.500 & 0.170 \\
\hline
\end{tabular}

Table 1 shows that the Clinical and Non-Clinical Groups differed regarding the reported complaints of behavioral problems, with the clinical group presenting higher means than the non-clinical group. On the other hand, the nonclinical group reported more hse-p, children's social skills, context variables and positive total. The result of the QRSHPais also demonstrated a significant difference between the groups, in which the non-clinical group showed higher means of social skills than the clinical group. In PHQ-4, the groups also differed statistically, since the clinical group had higher 
means of total score, as well as in the score of symptoms of depression when compared with the non-clinical group. In the score related to anxiety symptoms, no differences were observed between the groups. Groups of Boys and Girls did not show significant differences in any of the categories of the RE-HSE-P, QRSH and PHQ-4 instruments.

According to Table 2, the Groups of Clinical Girls and Non-Clinical Girls differed significantly in negative practices and complaints of behavior problems (RE-HSE-P), in which the group of Clinical Girls showed higher averages when compared with the group of Non-Clinical Girls. The Group of Non-Clinical Girls, on the other hand, had higher scores in diversity of interaction contexts, as well as in hse-p, children's social skills and positive total (RE-HSE-P). The result of the QRSH-Pais also showed a significant difference between the groups, in which the non-clinical group showed higher means of social skills than the clinical group. In
PHQ-4, the Group of Clinical Girls had higher averages related to the symptoms of maternal depression. The groups did not differ regarding the total and anxiety score.

Clinical Boys and Non-Clinical Boys differed significantly in hse-p, social skills, total positive and in diversity of interaction contexts, in which the group of Non-Clinical Boys showed higher averages when compared with the group of Clinical Boys. Complaints of behavior problems were reported more frequently for the group of Clinical Boys. The QRSH-Pais result showed no significant difference between groups. In PHQ-4, the Group of Clinical Boys had higher scores on symptoms of maternal depression. The total anxiety and scores did not differentiate the groups.

Table 3 shows that the groups of Clinical Girls and Clinical Boys and the groups of Non-Clinical Girls and Non-Clinical Boys had no significant difference in any of the categories of the RE-HSE-P, QRSH-Pais and PHQ-4 instruments.

Table 2

Comparisons between Clinical Girls $(n=10)$ and Non-Clinical Girls $(n=10) /$ Clinical Boys $(n=10)$ and Non-Clinical Boys $(n=10)$ for the numerical variables of the RE-HSE-P, QRSH and instruments PHQ-4 (Mann-Whitney U test)

\begin{tabular}{|c|c|c|c|c|}
\hline \multirow{2}{*}{ Categories } & \multicolumn{2}{|r|}{ Non-clinical Girls } & \multirow[b]{2}{*}{$U$} & \multirow[b]{2}{*}{$P$} \\
\hline & \multicolumn{2}{|c|}{ Mean (Standard Deviation) } & & \\
\hline \multicolumn{5}{|l|}{ Diversity (RE-HSE-P) } \\
\hline HSE-P & $6.20(3.55)$ & $10.10(3.07)$ & 15.500 & 0.008 \\
\hline SS & $8.10(4.65)$ & $11.80(2.20)$ & 20.000 & 0.023 \\
\hline Context & $8.90(2.88)$ & $14.90(5.45)$ & 13.000 & 0.005 \\
\hline Negative Practices & $7.10(5.09)$ & $3.90(1.52)$ & 24.500 & 0.050 \\
\hline Behavior problem complaints (BP) & $7.70(3.80)$ & $2.10(1.37)$ & 10.500 & 0.003 \\
\hline Positive total & $19.70(10.14)$ & $40.30(9.62)$ & 5.000 & 0.001 \\
\hline Negative total & $14.70(9.90)$ & $7.80(2.97)$ & 30.500 & 0.139 \\
\hline Children's HS (QRSH) & $21.10(6.52)$ & $28.60(5.15)$ & 18.000 & 0.015 \\
\hline Total score (PHQ-4) & $6.70(4.57)$ & $3.40(3.44)$ & 25.000 & 0.057 \\
\hline Depression score (PHQ-4) & $3.50(2.22)$ & $1.30(1.33)$ & 20.500 & 0.024 \\
\hline Anxiety score (PHQ-4) & $3.20(2.39)$ & $2.10(2.18)$ & 35.500 & 0.260 \\
\hline \multirow{2}{*}{ Categories } & Clinical Boys & Non-clinical Boys & & \\
\hline & \multicolumn{2}{|c|}{ Mean (Standard Deviation) } & $U$ & $P$ \\
\hline \multicolumn{5}{|l|}{ Diversity (RE-HSE-P) } \\
\hline HSE-P & $5.90(1.97)$ & $9.90(2.33)$ & 10.500 & 0.003 \\
\hline SS & $6.60(2.72)$ & $14.10(3.07)$ & 2.000 & 0.000 \\
\hline Context & $7.50(4.14)$ & $17.60(3.66)$ & 4.000 & 0.000 \\
\hline Negative Practices & $4.50(3.34)$ & $3.50(1.35)$ & 41.000 & 0.487 \\
\hline Behavior problem complaints (BP) & $7.40(4.20)$ & $2.70(1.42)$ & 12.500 & 0.004 \\
\hline Positive total & $21.00(7.29)$ & $45.00(8.81)$ & 3.500 & 0.000 \\
\hline Negative total & $14.70(8.90)$ & $8.40(1.35)$ & 38.000 & 0.361 \\
\hline Children's HS (QRSH) & $23.78(7.34)$ & $27.80(6.32)$ & 32.500 & 0.185 \\
\hline Total score (PHQ-4) & $4.70(2.87)$ & $2.40(1.58)$ & 29.000 & 0.106 \\
\hline Depression score (PHQ-4) & $3.10(1.79)$ & $1.10(0.87)$ & 15.500 & 0.006 \\
\hline Anxiety score (PHQ-4) & $1.60(1.17)$ & $1.30(0.94)$ & 42.500 & 0.556 \\
\hline
\end{tabular}


Table 3

Comparisons between Clinical Girls $(n=10)$ and Non-Clinical Girls $(n=10) /$ Clinical Boys $(n=10)$ and Non-Clinical Boys $(n=10)$ for the numerical variables of the RE-HSE-P, QRSH and instruments PHQ-4 (Mann-Whitney U test)

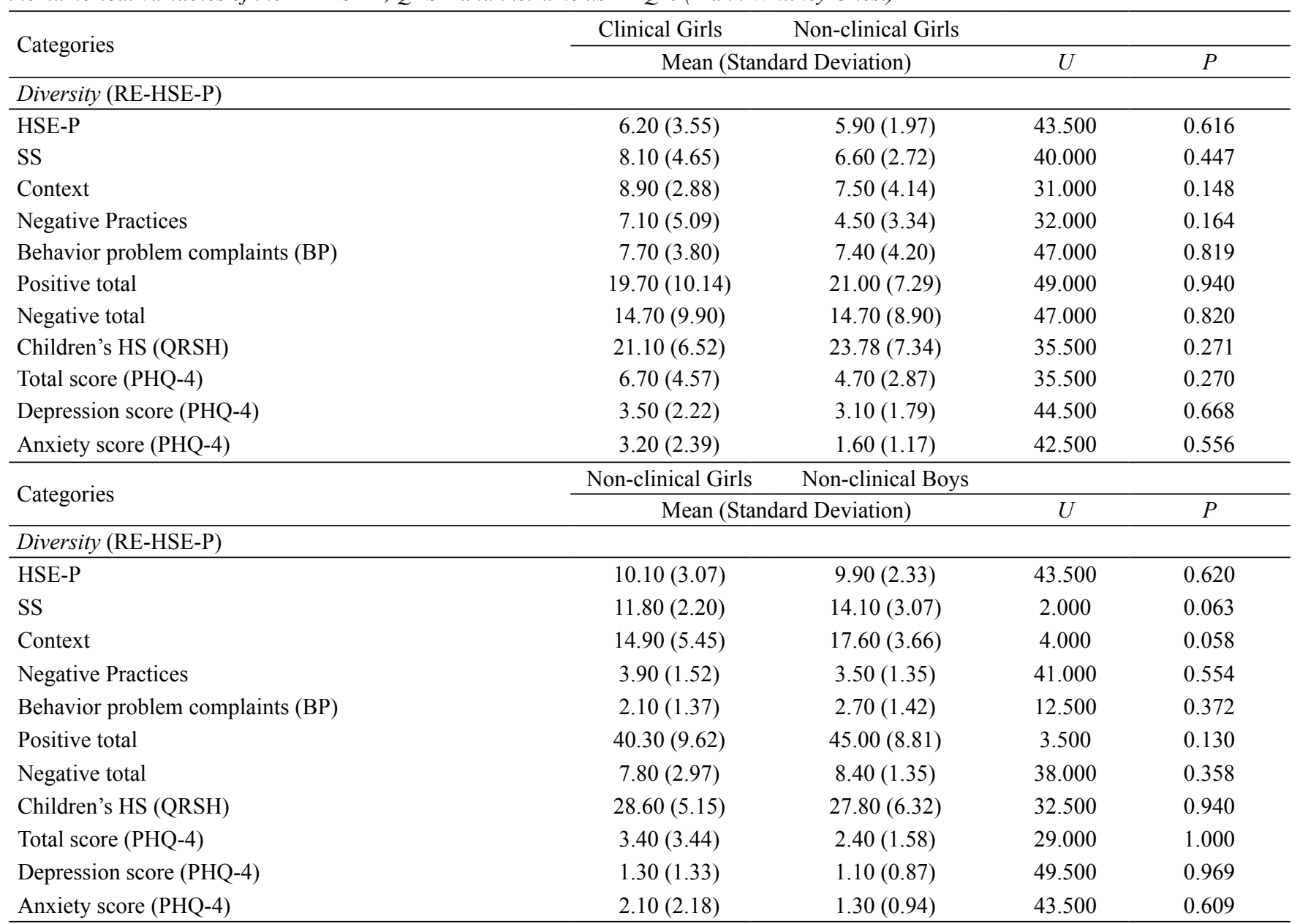

\section{Discussion}

Our study compared child behaviors, educational practices and maternal mental health in a case-control design. In general, the results showed that the clinical group had greater complaints of behavior problems, data supported by Hanisch, Hautmann, Plück, Eichelberg and Döpfner (2014). Mothers in the nonclinical group had a higher occurrence of hse-p and children had more social skills, in consistence with Borden et al. (2014), who found that non-clinical children had, more frequently and differently, social skills and, less frequently, behavior problems. According to Borden et al. (2014) and Clark and Frick (2018), children without behavior problems obey more frequently, both because parents are more affective and interact at different times, as well as because they are more contingent when setting limits. Thus, parents who with more educational social skills and less use of negative practices more often provide appropriate behavioral models, as well as encourage socially-skilled behaviors of their children (Fantinato \& Cia, 2015; Van Vugt et al., 2013, Waller et al., 2015).

Regarding maternal mental health, mothers of clinical children had higher scores related to symptoms of depression, in consistence with Alvarenga et al. (2012) and in Mian et al. (2009), who identified maternal depressive symptoms as one of the greatest risk factors for the development of cognitive, emotional and behavioral problems in children of school and pre-school age. Our findings also corroborate a study by Rakow et al. (2009), who found that depressed mothers used negative educational practices more frequently. They are consistent with Mendes, Loureiro and Crippa (2008), who found, in a literature review, that children of mothers with depression were exposed to a range of stressors, such as hostile environments, family discord and occupational problems. Thus, we emphasize the importance of developing early care in maternal and child mental health due to the impact of maternal depression on children's educational practices and behaviors.

The groups did not differ regarding the symptoms of maternal anxiety, which reinforces the hypothesis that there is a different association between depression and maternal anxiety and the behavior of school-aged children. Although conducted with children at a different age than in our study, Morais et al. (2017) also did not find associations of anxiety symptoms with the mother-child relationship. On the other hand, investigations with babies have found a relationship between maternal 
anxiety and child behaviors (Rodrigues \& Nogueira, 2016; Veríssimo et al., 2003). Thus, our study addresses maternal anxiety among mothers of children at school age, which is little studied in the literature and the findings are not comparable due to the scarcity of studies, which indicates the need for further investigations in this direction.

Regarding the comparison between the group of boys and girls, no differences were found, both in the general groups and when separated considering the presence or absence of behavioral problems. This finding was consistent with other authors (Martín et al., 2014; Massola \& Silvares, 2005), who also did not find any significant differences between female and male children.

However, our findings are not consistent with the studies by Mariano and Bolsoni-Silva (2016) and by Pizato et al. (2014), who found higher scores for social skills in girls than in boys. These different results can be explained by the different methodologies and especially in the different designs, since in the study by Pizato et al. (2014), the authors assessed the variable "sex", but the presence or absence of behavior problems was not previously assessed. In a study by Mariano and Bolsoni-Silva (2016), the teacher was the only respondent, therefore, the presence or absence of behavior problems in the family environment could not be identified. Likewise, there was also no balanced sample regarding the occurrence of behavior problems and sex.

In the comparison between the group of clinical and nonclinical girls, clinical girls had higher scores for complaints of behavior problems, reported by their mothers, who, in turn, had more negative practices. These results pointed to a connection between negative educational practices and behavioral problems, which is supported by the literature (Price, Chiapa, \& Walsh, 2013). Thus, parents tend not to adequately respond to their children's skillful behaviors, either by just ignoring them or by responding inappropriately, and aggressively, when trying to control problematic behaviors. On the other hand, non-clinical girls had more social skills and their mothers had a higher occurrence in hse-p report. In the comparison between clinical and nonclinical boys, clinical boys had higher scores for complaints of behavior problems. Likewise, the mothers of non-clinical boys had higher averages for hse-p and the boys, more social skills for children. These results corroborate the findings by Pizato et al. (2014), in which children with high scores of social skills had low rates of behavioral problems.

No differences were found when comparing the group of clinical girls and clinical boys and non-clinical girls and non-clinical boys. Thus, our findings suggest that the children's behavior, more than their sex, influences the use of hse-p or negative practices, in opposition to authors who found that parents interacted with their children according to their sex (Sampaio \& Vieira, 2010; Trad, 1999; Wright et al., 2013). Thus, it seems important to assess sex when studying parenting practices and behavior problems.

One of the contributions of our study was its casecontrol design. Another contribution is in the assessment of variables, which is based on the clinical identification of the children with greater risks by two informants - teachers and mothers - since they had behavior problems both in school and in family environments. The study of maternal depression and anxiety and their relationship with schoolchildren's practices and behavior was also important due to the scarcity of studies. One of the limitations is the fact that the period from the 1st to the 5th year of elementary school includes different stages in the students' development course, which can be assessed in future studies. The instrument used to assess maternal mental health can be cited as a limitation, since it was validated for the Brazilian clinical population only regarding depression. It is important to emphasize that other screening instruments for depression and anxiety validated for the Brazilian population are already available and can be used in future studies.

Our findings also have implications for public policies. Considering that, based on the point of view of teachers and mothers, clinical children are at risk for social and academic development, since they were not receiving any care at the time of collection. Thus, it seems urgent to identify indicators of behavior problems at school and in the household and invest in interventions with teachers, parents and children to minimize risks and expand socially-skilled repertoires. Further studies are necessary to assess the variables "sex" and "occurrence of behavior problems", including the assessment of age and schooling, increasing the number of participants and including the father in the data collection. Future studies are suggested to include direct observation measures and specify types of educational practices for each type of behavior problem, since, in our study, hse-p and negative practices were analyzed in general, regardless of the internalizing, externalizing or mixed nature of their behavior problem. Furthermore, we think it is essential to invest in interventions that provide more positive and functional patterns of interaction, both between teacher and child, and between parents and child.

\section{References}

Achenbach, T. M., \& Rescorla, L. A. (2001). Manual for the ASEBA School-Age Forms \& Profiles. Burlington, VT: University of Vermont/Research Center for Children, Youth \& Families.

Airosa, S., \& Silva, I. (2013). Associação entre vinculação, ansiedade, depressão, stresse e suporte social na maternidade [Association between attachment, anxiety, depression, stress and social support in motherhood]. Psicologia, Saúde \& Doenças, 14(1), 64-77. Retrieved from http://www.scielo.mec.pt/scielo.php?script=sci arttext\&pid=S1645-00862013000100005

Alvarenga, P., Oliveira, J. M., \& Lins, T. (2012). O impacto da depressão materna nos problemas internalizantes de préescolares [The impact of maternal depression on preschoolers internalizing behavior problems]. Aletheia, (38-39), 94108. Retrieved from http://pepsic.bvsalud.org/scielo. php?script=sci_arttext\&pid=S1413-03942012000200008 
Bolsoni-Silva, A. T., Loureiro, S. R., \& Marturano, E. M. (2016). Comportamentos internalizantes: Associações com habilidades sociais, práticas educativas, recursos do ambiente familiar e depressão materna [Internalizing behavior problems and associations with social skills, educative practices, familiar resources and maternal depression]. Psico (Porto Alegre), 47(2), 111-120. doi:10.15448/1980-8623.2016.2.20806

Bolsoni-Silva, A. T., Marturano, E. M., \& Loureiro, S. R. (2011). Estudos de confiabilidade e validade do Questionário de Respostas Socialmente Habilidosas Versão para Pais - QRSH-Pais [Studies in reliability and validation of the Social Skills Questionnaire - Parents Version (SSQ-P)]. Psicologia: Reflexão e Crítica, 24(2), 227-235. doi:10.1590/S0102-79722011000200003

Borden, L. A., Herman, K. C., Stormont, M., Goel, N., Darney, D., Reinke, W. M., \& Webster-Stratton, C. (2014). Latent profile analysis of observed parenting behaviors in a clinic sample. Journal Abnormal Child Psychology, 42(5), 731-742. doi:10.1007/s10802-013-9815-z

Bordin, I. A. S., Mari, J. J., \& Caeiro, M. F. (1995). Validação da versão brasileira do "Child Behavior Checklist" (CBCL) (Inventário de Comportamentos da Infância e Adolescência): [Validation of the Brazilian version of the Child Behavior Checklist (CBCL): preliminary data]. Revista ABP-APAL, 17(2), 55-66.

Bordin, I. A., Rocha, M. M., Paula, C. S., Teixeira, M. C. T. V., Achenbach, T. M., Rescorla, L. A., \& Silvares, E. F. M. (2013). Child Behavior Checklist (CBCL), Youth Self-Report (YSR) and Teacher's Report Form (TRF): An overview of the development of the original and Brazilian versions. Cadernos de Saúde Pública, 29(1), 13-28. doi:10.1590/S0102-311X2013000100004

Bueno, A. C. W., Grossi, R., Santos, B. C., Silva, L. C., \& Moura, C. B. (2011). Comparação entre comportamentos apresentados por mães de pré-escolares clínicos e não clínicos em uma situação lúdica [Comparison of behaviors displayed by mothers of clinical and nonclinical preschoolers in a playing situation]. Revista Brasileira de Terapia Comportamental e Cognitiva, 13(2), 4-20. doi: 10.31505/rbtcc.v13i2.450

Clark, J. E., \& Frick, P. J. (2018). Positive parenting and callous-unemotional traits: Their association with school behavior problems in young children. Journal of Clinical Child \& Adolescent Psychology, 47(Suppl. 1), S242-S254. doi:10.1080/15374416.2016

Fantinato, A. C., \& Cia, F. (2015). Habilidades sociais educativas, relacionamento conjugal e comportamento infantil na visão paterna: Um estudo correlacional [Educational social skills, marital relationship and child behavior according to fathers: A correlational study]. Psico (Porto Alegre), 46(1), 120-128. doi:10.15448/19808623.2015.1.17330
Fraga, D. A., Linhares, M. B. M., Carvalho, A. E. V., \& Martinez, F. E. (2008). Desenvolvimento de bebês prematuros relacionado a variáveis neonatais e maternas [Development of preterm infants related to neonatal and maternal variables]. Psicologia em Estudo, 13(2), 335-344. doi:10.1590/S1413-73722008000200016

Gomide, P. I. C. (2014). Inventário de Estilos Parentais: Modelo teórico- Manual de aplicação, apuração e interpretação (3rd ed.) [Parenting Style Inventory: Theoretical model- Manual of application, calculation and interpretation]. Petrópolis, RJ: Vozes.

Hanisch, C., Hautmann, C., Plück, J., Eichelberg, I., \& Döpfner, M. (2014). The prevention program for externalizing problem behavior (PEP) improves child behavior by reducing negative parenting: Analysis of mediating processes in a randomized controlled trial. Journal of Child and Psychology and Psychiatry, 55(5), 473-484. doi:10.1111/jcpp.12177

Kroenke, K., Spitzer, R. L., Williams, J. B. W., \& Löwe, B. (2009). An ultra-brief screening scale for anxiety and depression: The PHQ-4. Psychosomatics, 50(6), 613-621. doi:10.1176/appi.psy.50.6.613

Löwe, B., Wahl, I., Rose, M., Spitzer, C., Glaesmer, H., Wingenfeld, K., ... Brähler, E. (2010). A 4-item measure of depression and anxiety: Validation and standardization of the Patient Health Questionnaire-4 (PHQ-4) in the general population. Journal of Affective Disorders, 122(1-2), 86-95. doi:10.1016/j.jad.2009.06.019

Mariano, M., \& Bolsoni-Silva, A. T. (2016). Comparações entre práticas educativas de professores, habilidades sociais e problemas de comportamento de alunos [Comparisons between teachers' educational practices, social skills and students' problem behavior]. Estudos e Pesquisas em Psicologia, 16(1), 140-160. Retrieved from http://pepsic.bvsalud.org/scielo.php?script=sci arttext\&pid $=$ S1808-42812016000100009

Martín, V., Granero, R., \& Ezpeleta, L. (2014). Comorbidity of oppositional defiant disorder and anxiety disorders in preschoolers. Psicothema, 26(1), 27-32. doi:10.7334/ psicothema2013.75

Massola, G. M., \& Silvares, E. F. M. (2005). A percepção do distúrbio de comportamento infantil por agentes sociais versus encaminhamento para atendimento psicoterapêutico [Perception of children's behavior disturbance by social agents and psychological referral]. Revista Interamericana de Psicologia, 39(1), 139-150. Retrieved from https://www. redalyc.org/pdf/284/28439114.pdf

Mendes, A. V., Loureiro, S. R., \& Crippa, J. S. (2008). Depressão materna e a saúde mental de escolares [Maternal depression and school-age mental health]. Revista de Psiquiatria Clínica, 35(5), 178-186. doi:10.1590/S0101-60832008000500002 
Mian, L., Tango, L. A., Lopes, J., \& Loureiro, S. R. (2009). A depressão materna e o comportamento de crianças em idade escolar [Maternal depression and school-aged children behavior]. Psicologia: Teoria e Pesquisa, 25(1), 29-37. doi:10.1590/S0102-37722009000100004

Morais, A. O. D. S., Simões, V. M. F., Rodrigues, L. S., Batista, R. F. L., Lamy, Z. C., Carvalho, C. A., ... Ribeiro, M. R. C. (2017). Sintomas depressivos e de ansiedade maternos e prejuízos na relação mãe/filho em uma coorte pré-natal: Uma abordagem com modelagem de equações estruturais [Maternal depressive symptoms and anxiety and interference in the mother/child relationship based on a prenatal cohort: An approach with structural equations modeling]. Cadernos de Saúde Pública, 33(6), e00032016. doi:10.1590/0102-311x00032016

Osório, F. L., Carvalho, A. C. F., Fracalossi, T. A., Crippa, J. A. S., \& Loureiro, E. S. R. (2012). Are two items sufficient to screen for depression within the hospital context? International Journal of Psychiatry in Medicine, 44(2), 141-148. doi:10.2190/PM.44.2.e

Pizato, E. C. G., Marturano, E. M., \& Fontaine, A. M. G. V. (2014). Trajetórias de habilidades sociais e problemas de comportamento no ensino fundamental: Influência da educação infantil [Trajectories of social skills and behavior problems in primary school: Influence of early childhood education]. Psicologia: Reflexão e Crítica, 27(1), 189-197. doi:10.1590/S0102-79722014000100021

Price, J. M., Chiapa, A., \& Walsh, N. E. (2013). Predictors of externalizing behavior problems in early elementary-aged children: The role of family and home environments. The Journal of Genetic Psychology, 174(4), 464-471. doi:10. 1080/00221325.2012.690785

Rakow, A., Forehand, R., McKee, L., Coffelt, N., Champion, J., Fear, J., \& Compas, B. (2009). The relation of parental guilt induction to child internalizing problems when a caregiver has a history of depression. Journal of Child and Family Studies, 18(4), 367-377. doi:10.1007/s10826-008-9239-5

Rodrigues, O. M. P. R., \& Nogueira, S. C. (2016). Práticas educativas e indicadores de ansiedade, depressão e estresse maternos [Educational practices and indicators of anxiety, depression and maternal stress]. Psicologia: Teoria e Pesquisa, 32(1), 35-44. doi:10.1590/0102-37722016012293035044

Sampaio, I. T. A., \& Vieira, M.L. (2010). A influência do gênero e ordem de nascimento sobre as práticas educativas parentais [Gender and birth order as parenting moderators]. Psicologia: Reflexão e Crítica, 23(2), 198-207. doi: 10.1590/S0102-79722010000200002

Trad, L. A. B. (1999). Problematizando concepções de família e processos de interação social no contexto do Programa de Saúde da Família - PSF [Problematizing family conceptions and social interaction processes in the context of the Family Health Program - PSF]. Interfaces: Revista de Psicologia, 2(1), 103-106.
Van Vugt, E. S., Deković, M., Prinzie, P., Stams, G. J. J. M., \& Asscher, J. J. (2013). Evaluation of a group-based social skills training for children with problem behavior. Children and Youth Services Review, 35(1), 162-167. doi:10.1016/j.childyouth.2012.09.022

Veríssimo, M., Alves, S., Monteiro, L., \& Oliveira, C. (2003). Ansiedade de separação materna e adaptação psicossocial ao pré-escolar [Maternal separation anxiety and the quality of preschooler's psychosocial adaptation]. Psicologia, Saúde \& Doenças, 4(2), 221-229. Retrieved from http://www.scielo.mec.pt/scielo.php?script=sci arttext\&pid $=$ S1645-00862003000200004

Waller, R., Gardner, F., Dishion, T., Sitnick, S.L., Shaw, D.S., Winter, C.E., \& Wilson, M. (2015). Early Parental Positive Behavior Support and Childhood Adjustment: Addressing Enduring Questions with New Methods. Social Development, 24 (2), 304-322. doi: 10.1111/sode.12103

Wright, A. W., Parent, J., Forehand, R., Edwards, M. C., Conners-Burrow, N. A., \& Long, N. (2013). The relation of parent and child gender to parental tolerance of child disruptive behaviors. Journal of Child and Family Studies, 22(6), 779-785. doi:10.1007/s10826-012-9632-y

Rafaela Pires Assis-Fernandes is a Master in Psychology of Development and Learning of the Faculdade de Ciências, Universidade Estadual Paulista, Bauru-SP, Brazil.

Alessandra Turini Bolsoni-Silva is an Associate Professor of the Faculdade de Ciências, Universidade Estadual Paulista, Bauru-SP, Brazil.

\section{Authors' Contribution:}

All authors made substantial contributions to the conception and design of this study, to data analysis and interpretation, and to the manuscript revision and approval of the final version. All the authors assume public responsability for content of the manuscript.

Received: Apr. 08, 2018

1st Revision: Jul. 13, 2018

2nd Revision: Sep. 12, 2018

Approved: Oct. 16, 2018

How to cite this article:

Assis-Fernandes, R. P., \& Bolsoni-Silva, A. T. (2020). Educational social skills and repertory of children differentiated by behavior and sex. Paidéia (Ribeirão Preto), 30, e3015. doi:http://dx.doi.org/10.1590/1982-4327e3015 